\title{
Teaching NeuroImages: Drowsiness, visual hallucination, grandiose delusion, and neologism of a 48-year-old man
}

Mao Liu, MD, Dr. med, Jing Zhang, MD, PhD, and Yuan Yang, MD, PhD

Neurology ${ }^{\circledR}$ 2020;95:e1613-e1614. doi:10.1212/WNL.0000000000010195

Figure 1 Neologism during ideographic handwriting

A

(A) Incomprehensible characters indicated by the patient to reflect "multidimensional meanings of the world." (B) Accurate word copying with additional ideographic recreation of the word "peremptory" (red arrows).

A 48-year-old man had received embolotherapy for bronchiectasis-induced severe hemoptysis 1 week before and presented with acute drowsiness of 10 hours. Neuropsychiatric assessment revealed hypersomnolence, amnesia, confabulation, visual hallucination, grandiose delusion, anomic aphasia, and neologism during ideographic handwriting (figure 1). MRI showed acute ischemic stroke involving the thalamic region supplied by left paramedian $\operatorname{artery}^{1,2}$ (figure 2). Aspirin and atorvastatin were initiated. His symptoms persisted for 15 days but improved significantly with $2 \mathrm{mg}$ risperidone after 1 week, and he almost fully recovered 1 month later. Visual hallucination, delusion, and ideographic neologism are atypical symptoms of single left paramedian infarct. ${ }^{1,2}$

\section{Study funding}

No targeted funding reported.

\section{Disclosure}

The authors report no disclosures relevant to the manuscript. Go to Neurology.org/ $\mathrm{N}$ for full disclosures.
Correspondence

Dr. Yang

yuanyang70@hotmail.com

\section{MORE ONLINE}

$\rightarrow$ Teaching slides

lww.com/WNL/B159

From the Departments of Neurology (M.L., Y.Y.) and Radiology (J.Z.), Tongji Hospital, Tongji Medical College, Huazhong University of Science and Technology, Wuhan, People's Republic of China.

Go to Neurology.org/N for full disclosures. 
Figure 2 Infarct of the thalamic region supplied by left paramedian artery

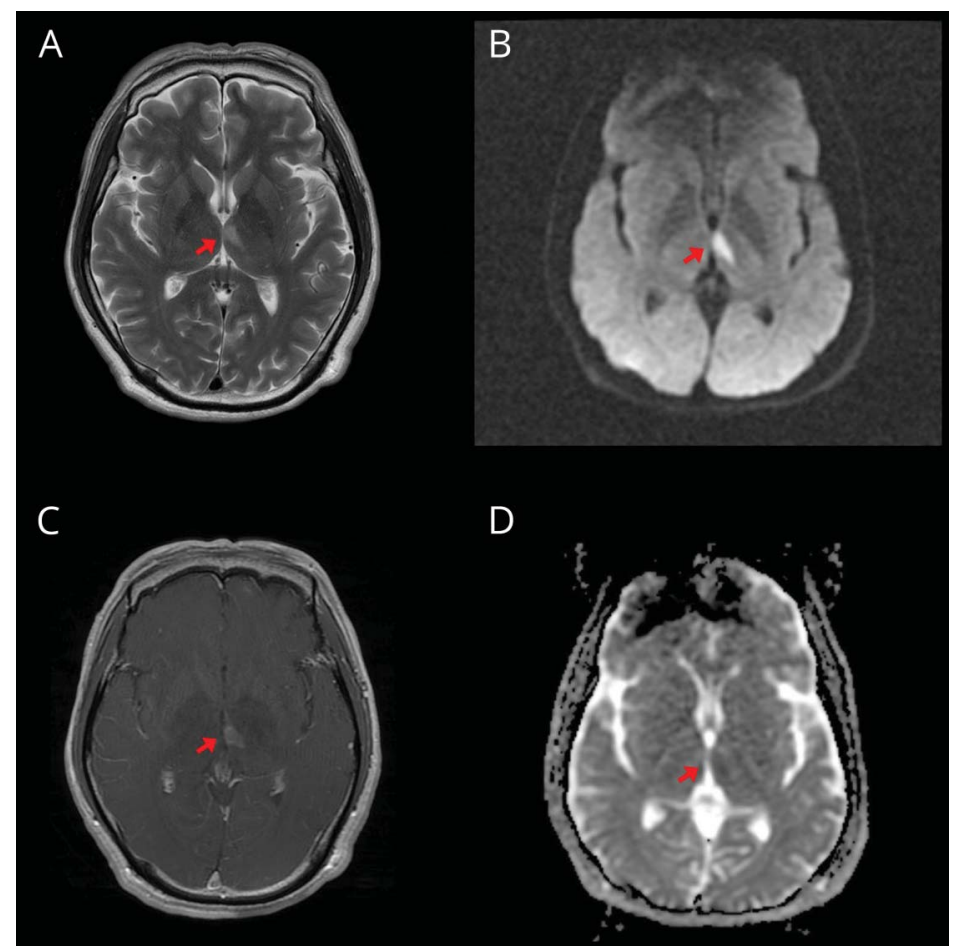

Acute infarction (red arrows) showing increased signal on T2 (A) diffusion-weighted imaging (B), and T1 contrast (C), and decreased signals on $A D C(D)$.

Appendix Authors

\begin{tabular}{|c|c|c|}
\hline Name & Location & Contribution \\
\hline $\begin{array}{l}\text { Mao Liu, } \\
\text { MD, } \\
\text { Dr. med }\end{array}$ & $\begin{array}{l}\text { Tongji Medical College, } \\
\text { Huazhong University of } \\
\text { Science and Technology, } \\
\text { Wuhan }\end{array}$ & $\begin{array}{l}\text { Designed the study; } \\
\text { collected, analyzed, and } \\
\text { interpreted the data; } \\
\text { wrote and revised the } \\
\text { manuscript }\end{array}$ \\
\hline $\begin{array}{l}\text { Jing } \\
\text { Zhang, } \\
\text { MD, PhD }\end{array}$ & $\begin{array}{l}\text { Tongji Medical College, } \\
\text { Huazhong University of } \\
\text { Science and Technology, } \\
\text { Wuhan }\end{array}$ & $\begin{array}{l}\text { Analyzed and interpreted } \\
\text { the data; revised the } \\
\text { manuscript }\end{array}$ \\
\hline
\end{tabular}

\section{Appendix (continued)}

\begin{tabular}{lll}
\hline Name & Location & Contribution \\
\hline Yuan & $\begin{array}{l}\text { Tongji Medical College, } \\
\text { Yang, }\end{array}$ & $\begin{array}{l}\text { Designed the study; } \\
\text { interpreted the data; } \\
\text { MD, PhD }\end{array}$ \\
$\begin{array}{l}\text { Science and Technology, } \\
\text { Wuhan }\end{array}$ & $\begin{array}{l}\text { revised the manuscript } \\
\end{array}$ \\
\hline
\end{tabular}

\section{References}

1. Schmahmann JD. Vascular syndromes of the thalamus. Stroke 2003;34:2264-2278.

2. Carrera E, Bogousslavsky J. The thalamus and behavior: effects of anatomically distinct strokes. Neurology 2006;66:1817-1823. 


\section{Neurology}

\section{Teaching NeuroImages: Drowsiness, visual hallucination, grandiose delusion, and neologism of a 48-year-old man \\ Mao Liu, Jing Zhang and Yuan Yang}

Neurology 2020;95;e1613-e1614 Published Online before print July 7, 2020

DOI 10.1212/WNL.0000000000010195

This information is current as of July 7, 2020

\section{Updated Information \& Services}

References

Subspecialty Collections

\section{Permissions \& Licensing}

Reprints including high resolution figures, can be found at: http://n.neurology.org/content/95/11/e1613.full

This article cites 2 articles, 2 of which you can access for free at: http://n.neurology.org/content/95/11/e1613.full\#ref-list-1

This article, along with others on similar topics, appears in the following collection(s):

\section{Aphasia}

http://n.neurology.org/cgi/collection/aphasia

Hallucinations

http://n.neurology.org/cgi/collection/hallucinations

Infarction

http://n.neurology.org/cgi/collection/infarction

MRI

http://n.neurology.org/cgi/collection/mri

Neuropsychological assessment

http://n.neurology.org/cgi/collection/neuropsychological_assessment

Information about reproducing this article in parts (figures,tables) or in its entirety can be found online at:

http://www.neurology.org/about/about_the_journal\#permissions

Information about ordering reprints can be found online:

http://n.neurology.org/subscribers/advertise

Neurology ${ }^{\circledR}$ is the official journal of the American Academy of Neurology. Published continuously since 1951, it is now a weekly with 48 issues per year. Copyright @ 2020 American Academy of Neurology. All rights reserved. Print ISSN: 0028-3878. Online ISSN: 1526-632X.

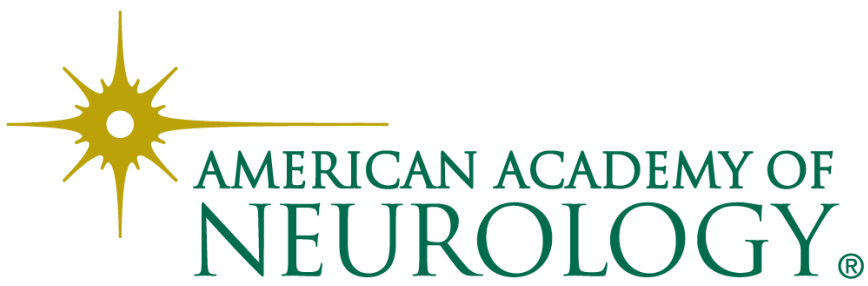

